\title{
Between León and the Levant: The Infanta Sancha's Altar as Material Evidence for Medieval History
}

\author{
Jitske Jasperse
}

\begin{abstract}
In the Museo de la Real Colegiata de San Isidoro in León, Spain, an intriguing portable altar is on display. Its multicolored stone and long inscription detailing the material objects enshrined within invite an analysis of the artwork in terms of materiality and mobility. This article addresses the multiple questions raised by the altar, shifting away from a straightforward interpretation of patronage by Sancha of León-Castilla (ca. 1095-1159), whose name is inscribed on its face. Conceptualizing the altar as a multilayered object that can be placed within Sancha's network of connections facilitates our understanding of this exotic artifact between León and the Levant.
\end{abstract}

\section{Keywords}

Infanta Sancha - portable altar - materiality - exoticism - León - Levant

"Queen Sancha, [daughter] of Raimundo, silvered me." So begins the inscription on a portable altar that is kept at the Museo de la Real Colegiata de San

1 For their stimulating comments, I would like to thank the participants of the conference The Medieval Iberian Treasury in the Context of Muslim-Christian Interchange (19-20 May 2017, held at the Princeton Institute for International and Regional Studies at Princeton University), and those attending the ICMA-sponsored session The Treasury of San Isidoro de León and Its Global Connections (4th Forum Medieval Art, Berlin-Brandenburg, 20-23 September 2017). I am also grateful to Eduardo Álvarez Aller for sharing his unpublished paper on Sancha's altar with me. Special thanks go to Jaroslav Folda and Warren Woodfin for their thoughts on the stone and the inscription, and above all to Therese Martin, who introduced me to Iberia, Sancha, and her altar. I am also indebted to her and to the anonymous reader for helping to improve my text. This article was written during my postdoctoral fellowship 
Isidoro de León (Figure 6.1). ${ }^{2}$ The "queen" is Sancha of León-Castilla (ca. 10951159), daughter of Queen Urraca of León-Castilla (r. 1109-1126) and Count Raimundo of Burgundy (d. 1107), and the elder sister of King Alfonso VII of León-Castilla (r. 1126-1157). ${ }^{3}$ Her altar has a long inscription detailing its date of consecration, the name of the bishop who blessed it, and an extensive list of relics. For medievalists, the story told by this altar is assumed to be a familiar one: the patron, Sancha, appears to have commissioned a personal portable altar that she eventually gave to her favored institution, San Isidoro de León. According to the Liber miraculorum beatissimi Isidori, written by Lucas of Tuy between 1221/24 and 1239, she presented vessels and vestments from her chapel to San Isidoro when she felt her death was near. ${ }^{4}$ Indeed, in this the earliest

(Juan de la Cierva-Formación, FJCI-2014-22406) at the Instituto de Historia, Consejo Superior de Investigaciones Científicas, Madrid and was generously supported by The Medieval Treasury across Frontiers and Generations: The Kingdom of León-Castilla in the Context of Muslim-Christian Interchange, c. 1050-1200 (PI, Therese Martin, Spanish Ministry of Economy and Competitivity, HAR2015-68614-P).

2 Portable Altar, 1144, $26.5 \times 17.2 \times 2.2 \mathrm{~cm}$, silver and gilded silver, engraved with niello, breccia di Aleppo. León, Real Colegiata de San Isidoro, Inv. No. IIC-3-089-002-0oo8. In Spanish publications this object is usually discussed in connection to Sancha and/or the treasure at San Isidoro. See Julio Pérez Llamazares, El tesoro de la Real Colegiata de San Isidoro de León. Reliquias, relicarios y joyas artísticas (León: Imprenta y Librería Religiosa, 1925), 175-180; Manuel Gómez-Moreno, Catálogo monumental de España: Provincia de León (1909-19o8), 2 vols. (Madrid: Ministerio de Instrucción Pública y Bellas Artes, 1925), 1:206-207; Ángela Franco Mata, "El tesoro de San Isidoro y la monarquía leonesa," Boletín del Museo Arqueológico Nacional 9/1-2 (1991): 35-68 at 67; Clara Bango García, "Ara de San Isidoro (León)," in Maravillas de la España medieval. Tesoro sagrado y monarquía, 2 vols., ed. Isidro G. Bango Torviso (Valladolid: Junta de Castilla y León, 2001), 1:352-353; and Eduardo Álvarez Aller, "El ara de la infanta doña Sancha en el tesoro de San Isidoro de León" (unpublished MA thesis, Universidad de Oviedo, 2010), 1-17. See also Michael Budde, Altare Portatile: Kompendium der Tragaltäre des Mittelalters 6oo-16oo, 2 vols. (Münster/Westf.: Werne a.d. Lippe, 1998), 2:cat. 98; and Gregoria Cavero, "Sancha Raimúndez: An Infanta in the Exercise of Her Power," Imago Temporis. Medium Aevum 7 (2013): 271-297, at 285.

3 For Sancha, see Luisa García Calles, Doña Sancha, hermana del Emperador (León: Centro de Estudios e Investigación San Isidoro, CSIC, 1972); María Encarnación Martín López, "Colección documental de la Infanta Doña Sancha (1118-1159): Estudio crítico," in León y su historia: Miscelánea histórica VIII (León: Centro de Estudios e Investigación San Isidoro. Caja España de Inversiones y Archivo Histórico Diocesano, 2003); Therese Martin, Queen as King: Politics and Architectural Propaganda in Twelfth-Century Spain (Leiden: Brill, 2006), 153-176; and Cavero, "Sancha Raimúndez," 271-297.

4 "Y al tiempo de su muerte la dió a la dicha iglesia [...] con todo el aparato, y ornamentos muy ricos de su capilla y con muchas y grandes reliquias de santos, que tenía." Lucas de Tuy, Milagros de San Isidoro, traducción Juan de Robles (1525), transcripción, prólogo y notas Julio Pérez Llamazares (1947) (León: Universidad de León y Cátedra de San Isidoro, 1992), chapter XXXvi, 65 . There is no Latin edition of the Miracles; Patrick Henriet is currently preparing one for Brepols. See also Chpt. 2 by Therese Martin, "Caskets of Silver and Ivory from Diverse 
extensive narrative text about the monastery, Sancha is presented as a devout donor who divided a piece of the True Cross among four crosses newly made of silver and gold. The largest of these, decorated with fragments of the Holy Sepulchre as if they were pearls, she gave to San Isidoro. ${ }^{5}$

Yet, closer analysis of the portable altar suggests a much more complicated history than the clear-cut patronage story outlined above. The present article addresses questions raised by a close examination of the altar's inscription, iconography, style, and exotic altar stone. Rather than claiming to provide definitive answers, the responses to these questions seek to deepen our understanding of the complexity of medieval objects by analyzing the altar's multilayered meanings. ${ }^{6}$ This moveable artifact is studied within the context of a network of actors who crossed regional boundaries to favor their chosen institutions.

Before locating Sancha and the altar within a web of persons and places, first the seemingly simple altar itself needs to be complicated. This object is less straightforward than it seems, a composite work in which inscription, iconography, and materiality function together. I begin by analyzing each element as separate though interconnected pieces of the puzzle. This approach to an

Parts of the World: Strategic Collecting for an Iberian Treasury," in this volume. On the Liber miraculorum beatissimi Isidori, see Patrick Henriet, "Hagiographie et politique à León au début du XIIIe siècle. Les chanoines réguliers de Saint-Isidore et la prise de Baeza," Revue Mabillon. Revue internationale d'histoire et de littérature religieuses, nouvelle série 8 (1997): 5382, at 58-59. For an example of a chapel, its use, and its importance to a ruler, see Chpt. 3 in this volume by Ana Rodríguez, "Narrating the Treasury: What Medieval Iberian Chronicles Choose to Recount about Luxury Objects."

5 "Y así, habida a dicha reliquia muy preciosa de Ligno Domini, mandó hacer la bienaventurada reina cuatro cruces de oro, y de plata, e hizo partir por partes y asentar en las dichas cruces aquella gran reliquia del madero del Señor, el cual, no solamente los hombres, más los ángeles adoran con mucha reverencia [...] Dió a la dicha iglesia de San Isidro, su esposo, la mayor de aquellas santas cruces, en la cual, demás y allende el Ligno Domini, había hecho ingerir muchos pedazos del sepulcro de Nuestro Señor y están engastados en ella a manera de perlas; la segunda cruz dió a la iglesia de la siempre Virgen Santa María, que es la iglesia catedral de la ciudad de León, y allí hace Nuestro Señor por aquella su santa cruz muchos y espesos milagros; la tercera cruz dió al monasterio de los gloriosos mártires San Facundo y San Primitivo; la cuarta cruz y menor, conviene a saber, aquella que había sido probada por el fuego en la manera susodicha, guardóla para sí en su tesoro." Milagros de San Isidoro, chapter xxxvi, 63 and 65. Sancha's pieces of the True Cross are not catalogued in A. Frolow, La relique de la Vraie Croix: recherches sur le développement d'un culte (Paris: Institut Français d'Etudes Byzantines, 1961).

6 Elina Gertsman and Asa Simon Mittman, "Rocks of Jerusalem: Bringing the Holy Land Home," in Natural Materials of the Holy Land and the Visual Translation of Place, 500-1500, ed. Renana Bartal, Neta Bodner, and Bianca Kühnel (London and New York: Routledge, 2017), 157-171. 


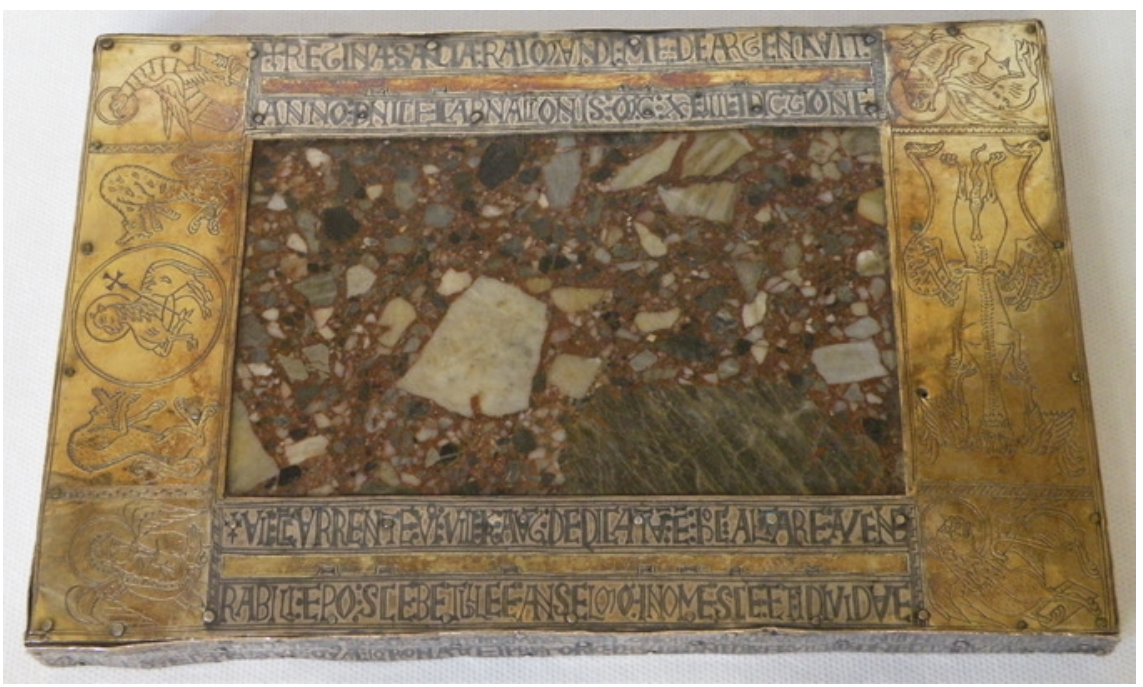

FIGURE 6.1 Portable Altar of the Infanta Sancha, 1144, $17.2 \times 26.5 \times 2.2 \mathrm{~cm}$, silver and gilded silver, niello, breccia di Aleppo (Museo de la Real Colegiata de San Isidoro de León, Inv. No. IIC-3-089-002-0008).

PHOTO: THERESE MARTIN

artwork is part of the art historian's traditional métier; although not the only way to study medieval artifacts, it helps to illuminate why iconography, style, and material should matter to all medievalists.

Inscribed artifacts hold a special place in the heart of the (art) historian. ${ }^{7}$ They seem to promise that the text can tell us all we need to know, often providing names of artists, patrons, and recipients, and highlighting, for example, that women played important roles in the creation of artworks in Middle Ages. ${ }^{8}$ Some inscriptions contain dates referring to manufacture, donation, or consecration, which support a geographical and chronological analysis and help us to recognize developments in ideas and cultural tastes. A number of inscriptions

7 For an analysis of medieval inscriptions, see Robert Favreau, Épigraphie médiévale. L'Atelier du Médiéviste 5 (Turnhout: Brepols, 1997); and Robert Favreau, "Les autels portatif et leurs inscriptions," Cahiers de Civilisation Médiévale 46/184 (2003): 327-352.

8 See the studies in Therese Martin, ed., Reassessing the Roles of Women as "Makers" of Medieval Art and Architecture (Leiden: Brill, 2015 [first ed. 2012]). 
reveal why they were commissioned, offering an insight into the patrons' (and the artists') preoccupations, thus shedding light on medieval mentalities. ${ }^{9}$ Reliquaries may be inscribed with lists enumerating the holy remains enshrined within, serving as inventories. In many cases, the inscriptions lend authority to the artworks, since they confirm in writing both making and existence. ${ }^{10}$ In fact, inscriptions can be such rich treasure troves of information that it is easy to forget that they are not necessarily reliable testimonials. It is important to keep in mind that these inscribed words were visually presented to their audience in a deliberate way. ${ }^{11}$ The portable altar of Sancha offers a case in point.

The commencement of the niello inscription is positioned on the altar's face, above and below the stone, in relatively large Caroline lettering on silver ground:

+ REGINA: SANCIA: RAIMVNDI: ME: DEARGENTAVIT: ANNO: DNICE: İCARNACIONIS: M: C: XL: IIII: İ DICTIONE:

+ VII: CCURRENTE: VI: VIII: KA: AVG: DEDICATV: Ẽ: HOC: ALTARE: AVENE/RABILI: EPO: SCE: BETHLLEE: ANSELMO: INOME: SCE: ET: IDIVIDVE: / 12

Queen Sancha, [daughter] of Raimundo, silvered me. In the year 1144 since the Incarnation of the Lord, seventh indiction, sixth concurrent, on the eighth day before the Kalends of August [25 July], this altar was dedicated by the venerable Anselm, bishop of Holy Bethlehem, in the name of the holy and undivided [Trinity].

$9 \quad$ Budde, Altare portatile, 1:773-774.

10 Vicente García Lobo and María Encarnación Martín López (with Santiago Domínguez Sánchez and Ana Isabel Suárez González), De epigrafía medieval: Introducción y album (León: Universidad de León, 1995).

11 This is stressed in Viewing Inscriptions in the Late Antique and Medieval World, ed. Antony Eastmond (Cambridge: Cambridge University Press, 2015).

12 With some minor alterations, the inscription is taken from Bango García, "Ara de San Isidoro (León)," 1:352-353. I want to thank Ilse Slot and Eduardo Fernández Guerrero for helping me with the inscription and its transcription. Julio Pérez Llamazares, abbot of San Isidoro in the 1920s, was the first to publish the full inscription on Sancha's altar, which he refers to as "el ara de San Isidoro." See Llamazares, El tesoro de la Real Colegiata, 180. A good reproduction of the inscription can be found in García Lobo and Martín López, De epigrafía medieval, plate XxI; see 103 for an analysis of the Caroline script. Manuel Gómez-Moreno identifies the script as Spanish in his Catálogo monumental de España, 1:206 and 2:fig. 225. Bango García follows this analysis ("Ara de San Isidoro [León]," 353), but it is unclear what either of them means by "tipo español," perhaps the "Spanish character" of this Caroline script? 
It is significant that Sancha is not styled infanta but regina, an honorary title that can be found in her charters from 1147-1148 onwards..$^{13}$ This makes the portable altar the earliest surviving testimony to the use of the queenly title by the ruler's unmarried sister, which would transfer just a few years later from silver to parchment. The inscription associates "Regina Sancia" with Raimundo of Burgundy, her father, who held jurisdiction as count over parts of Portugal and Leonese Extremadura through his marriage to Urraca, the eldest daughter of King Alfonso VI (r. 1065-1109). ${ }^{14}$ The choice to include only the count's name on Sancha's altar is unusual; in the contemporary documents issued by the infanta, she is routinely connected to both her father and mother, or to her brother the emperor, or to all three of them together. With the exception of a single charter, ${ }^{15}$ she is never styled the daughter just of Queen Urraca or of Count Raimundo, nor are her parents ever presented without their titles. Would a royal princess, who habitually displays such emphatic dynastic selfawareness in her charters, choose to refer to her only non-royal family member on her portable altar? I will return to this question below in the context of the remainder of the inscription and the question of the origins of the altar.

If we were to accept at face value the statement connecting Sancha to the altar as the person who had it made of silver, our story could end here. However, as Elizabeth Carson Pastan and others have emphasized, scholarship on patronage entails more than a straightforward search for the person commissioning or donating artworks; rather, it includes the dynamics among all parties involved. ${ }^{16}$ In fact, the very inscription suggests a more complicated history. The use of the word "silvered" (like gilded or deauratus) appears in several medieval inventories of treasuries, but I have found no other example where the

13 Martín López, "Colección documental de la Infanta," nos. 38, 42, 52, 54, 59, 61, 64, 65, 67, $68,73,76,86,88,90$, and 94 . The introduction of regina has been connected by Martín López (182-183) to the arrival of a new scribe, Gudesteo, whose name first appears in an 1147 charter.

14 Bernard Reilly, "Count Raimundo of Burgundy and French Influence in León-Castilla (1087-1107)," in Church, State, Vellum, and Stone: Essays on Medieval Spain in Honor ofJohn Williams, ed. Therese Martin and Julie A. Harris (Leiden: Brill, 2005), 85-109.

15 This charter was issued in 1158: “Ego, igitur, regina domna Sancia Raemundi." The phrase is repeated in the closing statement of the document. See Santiago Domínguez, Colección documental medieval de los monasterios de San Claudio de León, monasterio de Vega y San Pedro de Dueñas (León: Centro de Estudios e Investigación San Isidoro, 2001), no. 17.

16 Elizabeth Carson Pastan, "Patronage: A Useful Category of Art Historical Analysis," in The Routledge Companion to Medieval Iconography, ed. Colum Hourihane (London, New York: Routledge, 2017), 340-355, with discussion of recent approaches to patronage issues. 
object describes itself as being silvered. ${ }^{17}$ Through its inscription this object explicitly acted as a participant in the creation of a network of relationships that included the artist, Sancha, her chaplain, God, the canons of San Isidoro, and their treasury. ${ }^{18}$

After the altar speaks in its own voice in the opening phrase, the rest of the inscription shifts to third person: "this altar was dedicated by the venerable Anselm, bishop of Holy Bethlehem in the name of the holy and undivided [Trinity]." The ending of this first part of the inscription is noteworthy since the final word, trinity, does not appear on the face of the altar; rather, it is the first word on the front edge, pulling the reader along to the continuation of the passage (Figure 6.2). ${ }^{19}$ Did the designer of the text know that there would be no space on the front for this word, or was its placement left to the silversmith? Perhaps the author favored the rhythm of "bethllee" and "idividue." Or it may have been that the specific word that had to follow "holy and undivided" was so evident to the reader that nothing was thought of relegating "trinity" to the next plane. What is clear, however, is that in order to actually read the word trinity and complete the dedicatory sentence, the altar needed to be held and manipulated.

Beyond this verbal displacement that gives evidence of manual movement, the most intriguing elements in the first section of the inscription are its dating and its consecrator. In Iberia the Hispanic era is the most commonly employed dating system until the thirteenth century for both inscriptions and charters, including those at San Isidoro, making the "Anno Domini Incarnationis" stand out for an object that has been assumed to be of Spanish manufacture. ${ }^{20}$ Even rarer is the presence of the indiction—referring to a fifteen-year cycle used in

17 For deargentus in medieval inventories, see Bernhard Bischoff, Mittelalterliche Schatzverzeichnisse. Von der Zeit Karls des Grossen bis zur Mitte des 13. Jahrhunderts, ed. Florentine Mütherich (Munich: Prestel-Verlag, 1967), 36,14f; 48,22; 73,18f; and 92,12f.

18 For an analysis of inscriptions as agents, see Olga Bush, "Poetic Inscriptions and Gift Exchange in the Medieval Islamic World," Gesta 56/2 (2017): 179-197.

19 Beate Fricke suggested in a personal communication that the unusual placement of the word "trinity" is reason to investigate the composition of the silver/niello. A technical analysis of the portable altar would not only contribute to a better understanding of its making, but also to corroborating its date and to determining whether the altar might still contain relics and/or textiles. For the importance of material and technical analyses, see Chpt. 4 in this volume by Ana Cabrera on the treasury's textiles. According to the Codex Calixtinus, a depiction of the Trinity appeared on the baldachin (1105-1106) above the main altar in the cathedral of Santiago de Compostela. See Manuel Castiñeiras, "El altar románico y su mobiliario litúrgico: frontales, vigas y baldaquinos," in Mobiliario y ajuar litúrgico en las iglesias románicas, coord. Pedro L. Huerta (Aguilar de Campoo: Fundación Santa María la Real, 2011), 11-75, at 28.

20 For the dating systems employed in inscriptions and the rarity of indiction in Iberia, see Favreau, Épigraphie Médiévale, 171-183, esp. 178. See also Mark A. Handley, “Tiempo e 


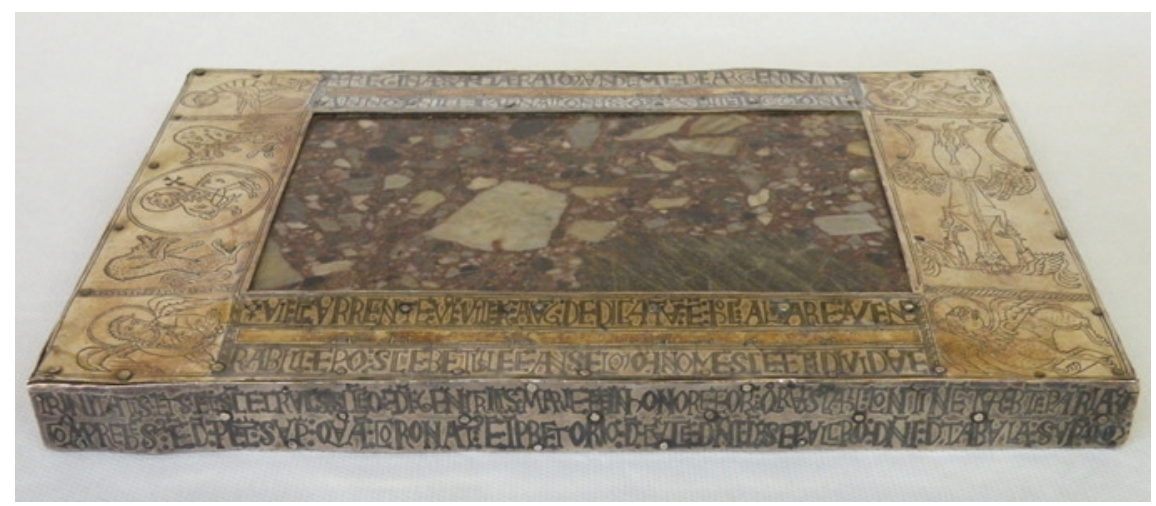

FIGURE 6.2 Portable Altar of the Infanta Sancha, front edge (Museo de la Real Colegiata de San Isidoro de León, Inv. No. IIC-3-089-002-0oo8).

PHOTO: THERESE MARTIN

the dating of documents - of which only three examples from the LeoneseCastilian area are known from the first quarter of the twelfth century. ${ }^{21}$ Two relevant examples, both connected to San Isidoro, deserve mention. The first is found in the eleventh-century Translatio S. Isidori Legionem an. 1063, written in León-Castilla, possibly by a Cistercian monk from France. ${ }^{22}$ In it both the indiction and concurrent are given, as they appear on the portable altar. The second indiction reference manifests itself in a document concerning Queen Urraca's donation of the Leonese monastery of San Salvador to San Isidoro, which was penned by a certain Ordoño who presents himself as "reginae notarius. ${ }^{23}$ This scribe may have been trained in France, where the indiction dating system was employed. ${ }^{24}$ The rarity of this type of dating in the Leonese

identidad: La datación por la era en las inscripciones de la España tardorromana y visigoda," Iberia 2 (1999): 191-201, at 192. For León, see Martín López, "Colección documental de la Infanta," 207; and Irene Ruiz Albi, La Reina doña Urraca (1109-1126): Cancillería y colección diplomática (León: Centro de Estudios e Investigación San Isidoro, 2003), 314-315.

21 Ruiz Albi, La Reina doña Urraca, 315.

22 "Reliquie uero beati confessoris ab Hyspalensi urbe translata atque Legionem sunt delata anno ab incarnatione domini nostri Ihesu Christi, Io.LX.III., indictione.I., concurrente.III." See José Carlos Martín, "La Translatio S. Isidori Legionem Anno 1063 (BHL 4488): Introducción, estudio y edición crítica," Exemplaria Classica. Journal of Classical Philology 15 (2011): 225-253, at 252. I would like to thank Julio Escalona Monge for bringing this reference to my attention.

23 "Facta testament series era MCLV, VIII idus septembris, anno ab Incarnatione Domini MCXVII, inditione decima." See Ruiz Albi, La Reina doña Urraca, no. 89, and 188-189.

24 For the use of indiction, see Reginald Lane Poole, Lectures on the History of the Papal Chancery down to the Time of Innocent III (Cambridge: Cambridge University Press, 
context, by contrast with the ubiquitous use of the Hispanic era, suggests that the designer of the altar's inscription hailed from elsewhere.

The specific date in 1144 that is commemorated on the portable altar is 25 July, and it is most unlikely that this was chosen at random as it is the feast day of St. James the Great, whose shrine at Santiago of Compostela attracted many pilgrims in this period. The connections between Compostela and the rulers of León-Castilla were tight, though not unproblematic. ${ }^{25}$ It remains unclear, however, whether this specific feast was chosen because St. James was the most prestigious saint on the Iberian Peninsula, or because the patron or owner felt a special veneration for him. The feast day combined with the Anno Domini and indiction may indicate that the maker of Sancha's altar was unfamiliar with the Hispanic era but well informed about the greatest saint in Spain.

Further, the name of the bishop who consecrated the altar also supports the idea that the object was not necessarily a Leonese or even an Iberian product. In order for altars, including portable ones, to be used during mass, they needed to be consecrated by a bishop. ${ }^{26}$ Sancha's altar was blessed not by a local Iberian bishop but by the "venerable Anselm, bishop of holy Bethlehem." In

1915); and Giles Constable, The Abbey of Cluny: A Collection of Essays to Mark the ElevenHundredth Anniversary of Its Foundation (Berlin: Lit. Verlag, 2010). In French inscriptions, however, the use of indiction appears to be less common than in documents, according to Robert Favreau, "La datation dans les inscriptions médiévales françaises," Bibliothèque de l'École des Chartes 157/1 (1999): 11-39, esp. 21-24. For French cultural impact on Iberia in this period, see Mercedes López-Mayán, "Culto y cultura en la catedral compostelana en el siglo XI," in En el principio: Génesis de la catedral románica de Santiago de Compostela. Contexto, construcción y programa iconográfico, ed. José Luis Senra (Santiago de Compostela: Teófilo Edicións, 2014), 31-56; José Luis Senra, "Cluny et l'Espagne," in Cluny (910-2010). Onze siècles de rayonnement, ed. N. Stratford (Paris: Éditions de Patrimoine, 2010), 354-363; and Reilly, "Count Raimundo of Burgundy," 85-109.

25 Carlos M. Reglero de la Fuente, "Reyes y obispos en los reinos de León y Castilla," in Reyes y prelados. La creación artística en los reinos de Leóny Castilla (1050-1500), ed. María Dolores Teijeira, María Victoria Herráez, and María Concepción Cosmen (Madrid: Silex Ediciones, 2014), 45-66.

26 Joseph Braun, Der christliche Altar in seiner geschichtlichen Entwicklung (Band 1): Arten, Bestandteile, Altargrab, Weihe, Symbolik (Munich: Alte Meister Guenther Koch \& Co., 1924), 426; Barbara Drake Boehm "Altar, Portable," in The Grove Encyclopedia of Medieval Art and Architecture, 6 vols., ed. Colum Hourihane (Oxford: Oxford University Press, 2012), 1:40-44, at 43; James Robinson, "From Altar to Amulet: Relics, Portability, and Devotion," in Treasures of Heaven: Saints, Relics and Devotion in Medieval Europe, ed. Martina Bagnoli, Holger A. Klein, C. Griffith Mann, and James Robinson (London: The British Museum Press, 2010), 111-116, at 112; and Éric Palazzo, L'espace rituel et le sacré dans le christianisme: la liturgie de l'autel portatif dans l'Antiquité et au Moyen Âge (Turnhout: Brepols, 2008), chapter 4 for a detailed analysis of the consecration rite. None of these publications mentions Sancha's altar. 
1107, at the request of Baldwin I, Pope Paschal II established Bethlehem as a bishopric. ${ }^{27}$ The see's second bishop, Anselm (fl. 1130-1142, d. ca. 1147), remains a sketchy figure. ${ }^{28} \mathrm{He}$ wrote a letter to Leo, dean of Reims, thanking him for the magnificent psalter the latter had sent him. ${ }^{29}$ Anselm also briefly figures in William of Tyre's History of Deeds Done beyond the Sea (ca. 1171-1184), where the bishop accompanied Geoffrey, the first abbot of the Templum Domini, and Rohard the Elder, viscount of Jerusalem, on a mission to Emperor John II Comnenus in Cilicia in $1142 .{ }^{30}$ There is, however, nothing to suggest that Bishop Anselm ever went to Spain, nor can he otherwise be connected to Sancha, her family, or to the Iberian Peninsula at all. One explanation may be that Anselm consecrated the altar (that is, the wooden box and stone) in Bethlehem and then sent it off to Sancha, who made sure that it was decorated properly. Whether Anselm made an undocumented journey to León or dispatched the altar from Bethlehem, both options place Sancha within a wider web of connections. Sancha and her altar are part of a larger history of interactions beyond the borders of her infantazgo; this is corroborated by her correspondence with Bernard of Clairvaux, discussed below, as it is by the remainder of the inscription.

From the word "Trinity," the silver niello text continues in small lettering along the front edge (see Figure 6.2). The epigraph as a whole, engraved in four separate strips nailed onto the narrow sides of the altar, must be read by first following the upper line on all sides (Figure 6.3, red arrows) and then the lower one (Figure 6.3, yellow arrows). This means that the inscription cannot be understood unless the altar is held in one's hand and turned around and around, an indication that it was designed to be handled intimately by a single individual. ${ }^{31}$

27 Jochen Burgtorf, "Bethlehem," in The Crusades: An Encyclopedia, 4 vols., ed. Alan V. Murray (Santa Barbara: ABC-CLIO Inc, 2006), 1:166-167, without mentioning Anselm.

28 Also known as Anseau, his death has been dated around 1142-1147, based on the first mention of the next bishop, Giraud, in 1147. See Charles du Fresne, Seigneur du Cange, Les familes d'outre-mer (Paris: Impr. Nationale, 1869), 784-785. Given the evidence of the portable altar, I would suggest that the range of dates for Anselm's death can be narrowed to $1144-1147$.

29 Letters from the East: Crusaders, Pilgrims and Settlers in the 12th-13th Centuries, trans. Malcolm Barber and Keith Bate (Farnham: Ashgate, 2010), no. 14.

30 Rudolf Hiestand, "Gaudefridus abbas Templi Domini: An Underestimated Figure in the Early History of the Kingdom of Jerusalem," in The Experience of Crusading, 2 vols., ed. Peter Edbury and Jonathan Philips (Cambridge: Cambridge University Press, 2003), 1:4859, esp. 50 for references to Anselm.

31 That shrines and their relics were handled is also highlighted by María Judith Feliciano in Chpt. 5 of this volume. She remarks that textiles function as veils in the rituals that concealed, revealed, protected, and exposed the relics at the moment of activation. 


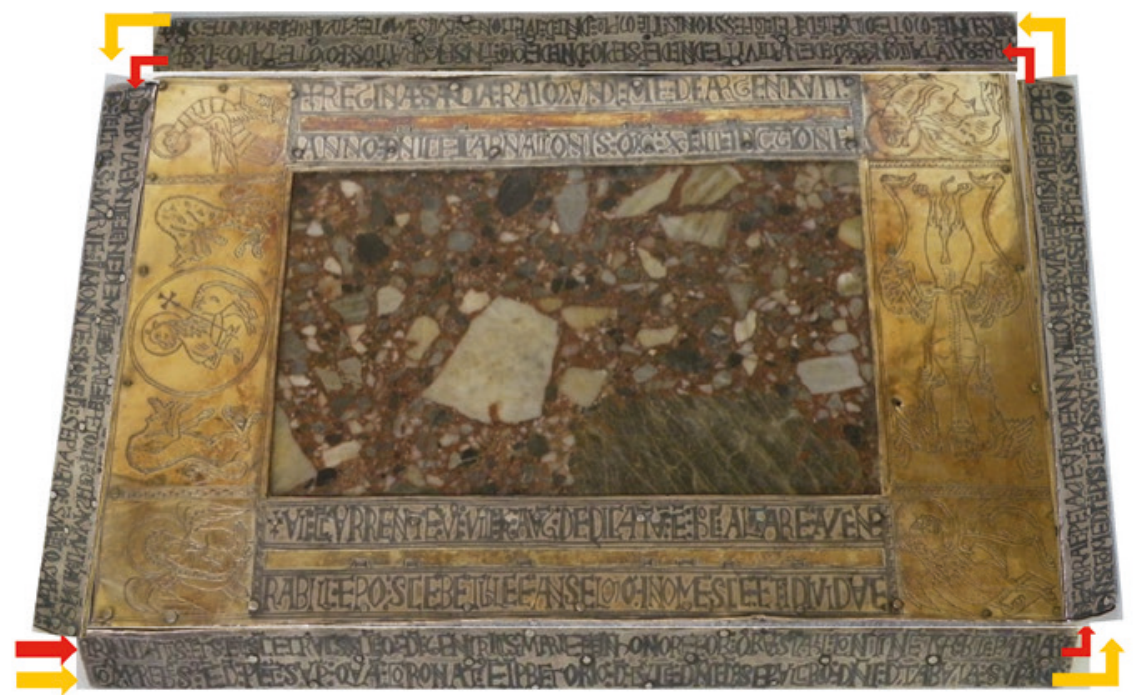

FigurE 6.3 Portable Altar of the Infanta Sancha, inscription on the edges (Museo de la Real Colegiata de San Isidoro de León, Inv. No. IIC-3-089-002-00o8). PHOTO: THERESE MARTIN; DESIGN: JITSKE JASPERSE

The two lines of text read:

TRINITATIS: ETS: ET: SCE: CRVCIS: SCCEQ: I: DI: GENITRICIS: MARIE: ET: INHONORE: EORU: QORV: SCA: HIC: CONTINETUR: BTI: PATRIARC/ HE: ABRAE: PELAGIE:VR: DE: ANNVNCIONE: SC: MAR: ET: HELISABET: E: PE/TRA: SALVTACIONS: S: M: DE: NATIVITE: DNI: DE: PSEPIO: DNI: DE: LOCO:TNSFIGVRATIOS: I: MOTE:T ABOR: DE: S: PRT/D :TABVLA: DNICE: CENE: DE: MOTE: CALVARIE: D: PETQ: DR: GETHSAMANI: VI: DNS:/

COMPREHES': E: D: PET: SUP: QVA: CORONAT: E: IPRETORIO: D: CRVCE: DNI: D: SEPVLCRO: DNI: DTABVLA: SVP: QM: /DNS: COMEDIT: PISCF: ASSV: ET: FAVV: MELLIS: D: PET: ASSCESSIO/NIS: DNI:I : MOTE: OLIVETI: D: PET: COFESSIONIS: I:TEMPLO: DNI: D: IVETIONE: S:CRUCIS: I: MOTE: CALVARIE:D: MONTE SINAI: /D: LECTO: S: MARIE: I: MONTE: SION: D: SEPULCRO: SM: I: IOSAPHAT:

[...] Trinity and [in the name of] of the sacred cross and of the most holy immaculate (?) mother of God, Mary, and in honor of those whose relics are contained here: of the blessed Patriarch Abraham, of the Virgin Pelagia, of the Annunciation to holy Mary and Elizabeth, of the stone of the greeting to holy Mary, of the birth of the Lord, of the crib of the Lord, of the location of the Transfiguration on Mount 
Tabor, of the Holy Spirit, of the table of the Last Supper, of Mount Calvary, of the rock called Gethsemane where the Lord was taken, of the stone where he was crowned at the fortress, of the Cross of the Lord, of the sepulcher of the Lord, of the table where the Lord ate fish, roast, and honeycomb, of the rock of the ascension of the Lord on the Mount of Olives, of the tomb stone in the temple of the Lord, of the finding of the Holy Cross on Mount Calvary, of Mount Sinai, of the bed of holy Mary on Mount Zion, of the sepulcher of Holy Mary in the valley of Jehoshaphat.

The two references to revered individuals (Abraham ${ }^{32}$ and Pelagia), ${ }^{33}$ together with the nineteen allusions to holy places, suggest that the portable altar once contained some twenty-one pieces of saintly material. Just three of the references—to Abraham, St. Pelagia, and Mount Sinai-are from something other than the lives of Christ and Mary, beginning with the Annunciation to the Virgin, through Jesus's childhood and ministry, and until the death of each. It should also be noted that it is not only a fragment of the True Cross that is included here, but also a relic of the finding of the Cross on Calvary, thus memorializing the holy actions of St. Helena, who was regarded as an exemplary model of queenship. ${ }^{34}$

32 For Abraham and other historical Jews in the treasury of San Isidoro, see Chpt. 8 by Julie Harris, "Jews, Real and Imagined, at San Isidoro de León and Beyond," in this volume. She also discusses Old Testament relics in the Arca Santa at the Cámara Santa of San Salvador de Oviedo, as well as León Cathedral's connections with Jews.

33 Pelagia was a "holy harlot," a reformed prostitute from Antioch who became a hermit living in a cave on the Mount of Olives where she was later buried. The Piacenza pilgrim, who visited the Holy Land before 570, is the first to report the site as a holy place, and it remained popular throughout the Middle Ages. See Ora Limor, "Sharing Sacred Space: Holy Places in Jerusalem between Christianity, Judaism, and Islam," in In Laudem Hierosolymitani: Studies in Crusades and Medieval Culture in Honour of Benjamin Z. Kedar, ed. Iris Shagrir, Ronnie Ellenblum, and Jonathan Riley-Smith (Aldershot: Ashgate, 2007), 219-231, esp. 227-228. As a female saint, Pelagia balances the presence of Abraham and, together with Helena (who is represented through the finding of the True Cross), Mary, and Elizabeth, Pelagia illustrates the significance of saintly women and their sites in the Holy Land.

34 The importance of Helena to the image of medieval queenship is underscored by Jo Ann McNamara, "Imitatio Helenae: Sainthood as an Attribute of Queenship," in Saints: Studies in Hagiography, ed. Sandro Sticca (Binghamton, NY: State University of New York Press, 1996), 51-80. An explicit connection between an elite woman and Empress Helena is found on the so-called Gunhild Cross (ca. 1075?) in its inscription: QUI IN CHRISTUM CRUCIFIXUM CREDUNT LIUTGERI MEMORIAM ORANDO FACIANT QUI ME SCULPSERAT ROGA TU HELENE QUE ET GUNHILD VOcatUR (Those who believe in the crucified 
Sancha's altar, then, does not contain the usual suspects, such as the apostles, martyrs, and bishops inscribed on the Hildesheim portable altar (Figures 6.4a-b); rather, it has more in common with the types of relics mentioned on the lid of the outsized Arca Santa in Oviedo (Figure 6.5). ${ }^{35}$ In much more detail than the Arca Santa, however, the collection of relics mentioned on Sancha's altar makes it possible to follow closely in the footsteps of Christ and Mary and to visit sacred places, as pilgrims did when they traveled to the Holy Land, in person or in the mind. ${ }^{36}$

The inscription presents a chronology starting with Mary's role as mother, then enumerating all the key moments in Christ's life along with the ordeals he had to suffer; it ends with the Virgin's death and the tomb left empty at her assumption. To make these events and places more real, references are made to stones and other tangible objects such as cribs and tables, beds and graves, even roast and honeycomb. They act as signifiers of locations and occurrences, helping to bring them to life and to place the reader at those specific sites. For that very reason, remarks about rocks, tombstones, and stone altars often feature in pilgrims' travel accounts. ${ }^{37}$

As is well known, this same impulse gave rise to the collecting of stones, sand, textiles, and fluids (tertiary relics or eulogia, blessed objects) that were

Christ shall in their prayers remember Liutgerus, who carved me at the behest of Helena, who is also called Gunhild). See Favreau, Épigraphie Médiévale, 122.

35 For the content of the Hildesheim article, see Maickel van Bellegem and Lloyd de Beer, "The Construction and Conversion History of the Hildesheim Portable Altar," in Matter of Faith: An Interdisciplinary Study of Relics and Relic Veneration, ed. James Robinson and Lloyd de Beer, with Anna Harnden (London: The British Museum, 2014), 126-136. For the Arca Santa, see Julie A. Harris, "Redating the Arca Santa of Oviedo," Art Bulletin 77 (1995): 82-93; César García de Castro Valdés, "Datos y observaciones sobre el Arca Santa de la Cámara Santa de la Catedral de Oviedo," Nailos: Estudios Interdisciplinares de Arqueología 3 (2016): 121-163, inscription at 143-144; and César García de Castro Valdés, El Arca Santa de la catedral de Oviedo (Aguilar de Campoo: Fundación Santa María la Real, Centro de Estudios del Románico, 2017).

36 The literature on virtual pilgrimages is vast. See, for example, Yamit Rachman-Schrire, "Sinai Stones on Mount Zion: Mary's Pilgrimage in Jerusalem," in Between Jerusalem and Europe: Essays in Honour of Bianca Kühnel, ed. Renana Bartal and Hanna Vorholt (Leiden: Brill, 2015), 57-73; Visual Constructs of Jerusalem, ed. Bianca Kühnel, Galit NogaBanai, and Hanna Vorholt (Turnhout: Brepols, 2014); and Gertsman and Mittman, "Rocks of Jerusalem," 157-171.

37 Daniel the Abbot mentions Christ's tomb, its cave, the stone where the crucifixion took place, the cave in the rock beneath the altar in the house of Joachim and Anna, the stone where Jacob had his dream, the tomb of the Virgin in a cave cut from rock, and the stone from which Christ ascended to heaven and beneath which is a marble altar slab. See John Wilkinson (with Joyce Hill and W. F. Ryan), Jerusalem Pilgrimage 1099-1185 (London: The Hakluyt Society, 1988), 128, 132, 134, and 135 . 

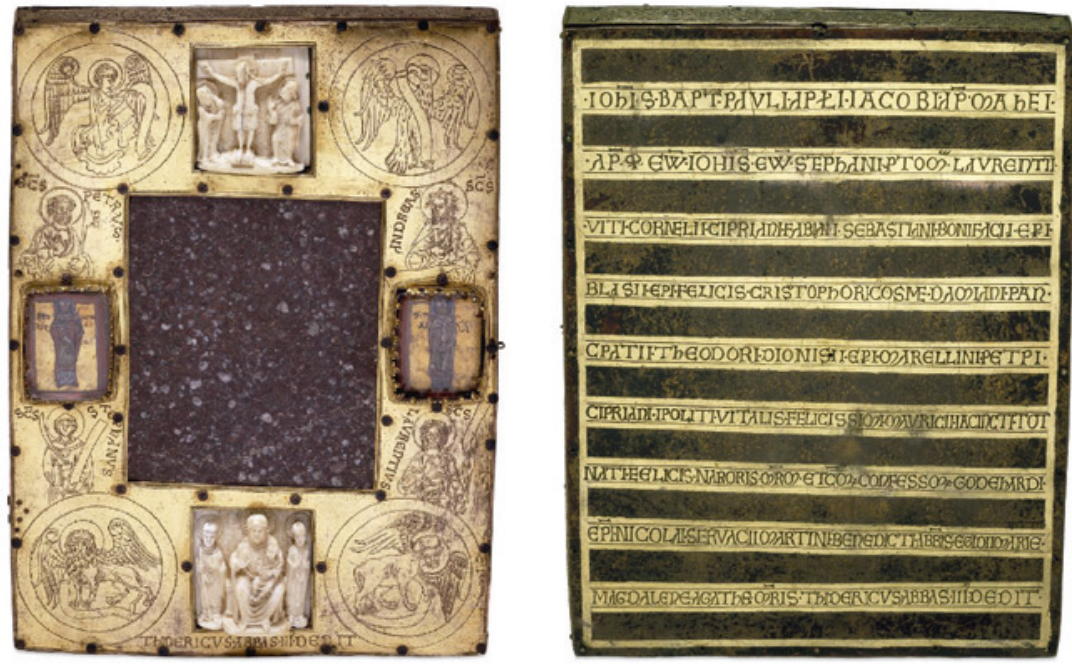

Figures 6.4A, B Portable Altar from Hildesheim, 119o-1200, $25.1 \times 35.4 \mathrm{~cm}$, engraved with vernis brun, red stone, gilt-copper, ivory, vellum under rock crystal (London, British Museum, museum number 1902,0625.1.).

SOURCE: (C) TRUSTEES OF THE BRITISH MUSEUM. CC BY-NC-SA 4.0

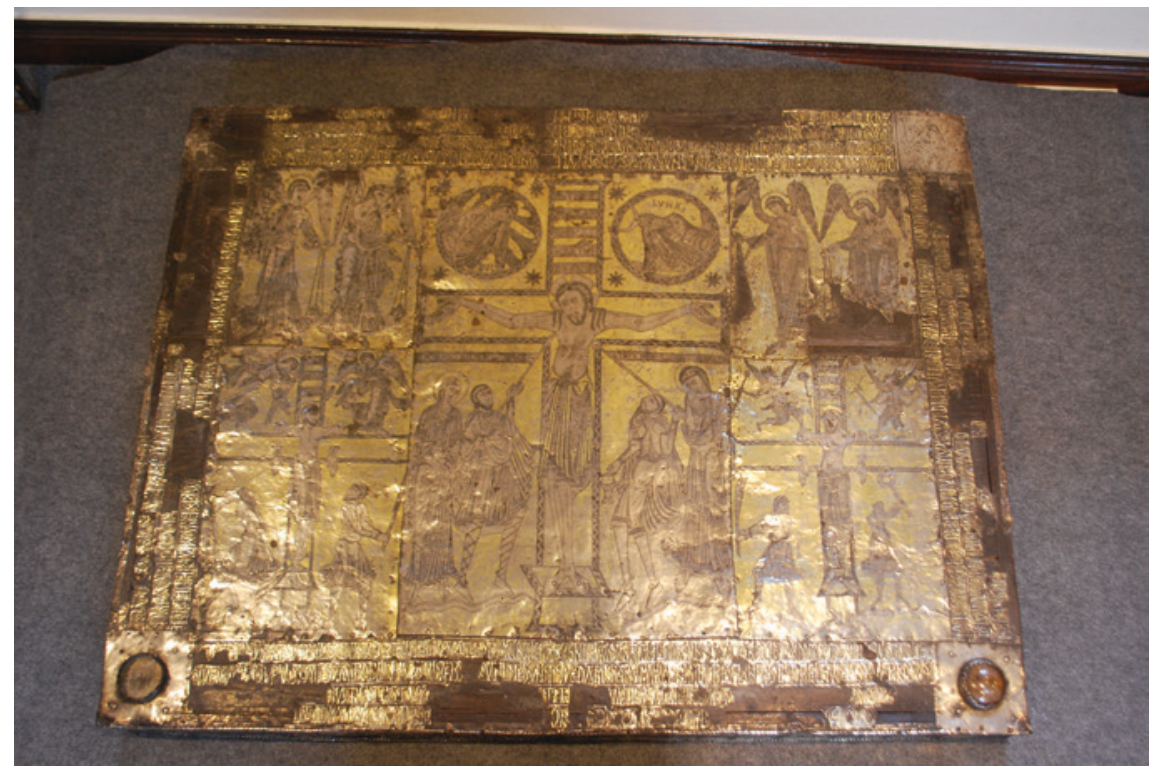

FIGURE 6.5 Lid of the Arca Santa, early twelfth century. Cámara Santa, Oviedo Cathedral, $93 \times 119.8 \times 9.5 \mathrm{~cm}$.

PHOTO: CÉSAR GARCÍA DE CASTRO VALDÉS 
connected to these sacred locations. ${ }^{38}$ In fact, Sancha's portable altar has more in common with reliquaries that contain stones, wood, or oil than with other portable altars, which usually hold body-part relics from holy individuals. Thus more than merely an inventory, this altar's inscription provides a biblical narrative by presenting materials, especially stones, which had the potential to transport the user from a physical site in Iberia to virtual yet real places in the Holy Land.

\section{The Lamb of God Attacked: Between León and the Levant?}

My analysis of the silver-niello inscription - with its unusual dating system, the presence of Bishop Anselm of Bethlehem, and the long list of site relicshas raised doubts about whether the altar was made in León, as has traditionally been assumed, suggesting instead that we should look to the Levant. In the twelfth century and beyond, "made in" labels are the exception rather than the rule. Places of manufacture, be it monastic environments or court workshops, have preoccupied art historians (and sometimes tormented historians) with discussions that tend to focus on style and iconography, which some scholars consider to be limited approaches. However, relationships between style and location do have implications for our understanding of places, people, and the movements of ideas and artworks. ${ }^{39}$ Whether Sancha's altar was made in León or the Levant might not necessarily impact our appreciation of the object as a portable altar. Yet it obliges us to rethink assumptions about Leonese courtly production and about the connections between Iberia and the Holy Land.

Art historians have taken a keen interest in royally sponsored workshops, such as those at Aachen under Charlemagne, at Palermo producing textiles

38 Katja Boertjes, "The Reconquered Jerusalem Represented: Tradition and Renewal on Pilgrimage Ampullae from the Crusader Period," in The Imagined and Real Jerusalem in Art and Architecture, ed. Jeroen Goudeau, Mariëtte Verhoeven, and Wouter Weijers (Leiden and Boston: Brill, 2014), 169-189, at 170; and Cristina Pantanella, "Reliquary Box with Stones from the Holy Land," in Treasures of Heaven: Saints, Relics and Devotion in Medieval Europe, ed. Martina Bagnoli, Holger A. Klein, C. Griffith Mann, and James Robinson (London: The British Museum Press, 2010), 36.

39 Meyer Schapiro famously argued that a specific style (an artistic ideal) was interwoven with historical events and could therefore reflect social changes and tensions. See Meyer Schapiro, "From Mozarabic to Romanesque in Silos," The Art Bulletin 21/4 (1939): 313-374; and John Williams, "Meyer Schapiro in Silos: Pursuing an Iconography of Style," The Art Bulletin 85 (2003): 442-468. See also Elizabeth Sears, "Style and Ideology," in Reading Medieval Images: The Art Historian and The Object, ed. Elizabeth Sears and Thelma K. Thomas (Ann Arbor, MI: The University of Michigan Press, 2002), 126-127. 
under Islamic and Christian rulers, and at Córdoba creating ivories during the caliphate. ${ }^{40}$ Through these workshops the patronage and ideologies of rulership were promoted. For León, John Williams has argued that the ivory cross of Fernando and Sancha, the gold and ivory casket of Saints John the Baptist and Pelayo, the ivory Beatitudes casket, and an ivory Traditio Legis plaque (now in the Louvre) "are so homogeneous stylistically that a Leonese ivory workshop of royal sponsorship must be assumed."41 Following this argument, although ignoring the significant shift in materials, scholars have assumed that Sancha's portable altar was made in León as well. Before addressing their reasoning, let us first examine the altar's decoration to see what clues it may provide. ${ }^{42}$

On the gilded face of the altar, the symbols of the evangelists are depicted in the four corners (see Figure 6.1). Each holds a book representing his respective gospel. By pairs, they turn their attention to the scenes they flank: at the top, Matthew and John witness two beasts that, with wide-open jaws, roar in frustration at the Agnus Dei protected by a clipeus. Below, Mark and Luke look on as a stretched-out animal that swallows two birds (roosters?) is in turn bitten by two fierce animals with long tails. ${ }^{43}$ The evangelists and Lamb of God are

$40 \quad$ For the court school in Aachen, see Wilhelm Köhler, Die karolingische Miniaturen 2: Die Hofschule Karls des Großen (Berlin: Deutscher Verein für Kunstwissenschaft, 1958). For a critical analysis of the concept of this court school, see Dieter Hägermann, "Der DagulfPsalter. Ein Zeugnis fränkischer Orthodoxie," in Von Sacerdotum und Regnum. Geistliche und weltliche Gewalt im frühen und hohen Mittelalter. Festschrift für Egon Boshof zum 65. Geburtstag, ed. Franz-Reiner Erkens and Hartmut Wolff (Cologne: Böhlau Verlag, 2002), 183-201, esp. 187-19o. For Palermo, see Isabelle Dolezalek, Arabic Script on Christian Kings: Textile Inscriptions on Royal Garments from Norman Sicily (Berlin: De Gruyter, 2017), 84-86. For Córdoba, see Noelia Silva Santa-Cruz, "Ivory Gifts for Women in Caliphal Córdoba: Marriage, Maternity and Sensuality," Journal of Medieval Iberian Studies 6/1 (2014): 103-125; Glaire D. Anderson and Mariam Rosser-Owen, "Great Ladies and Noble Daughters: Ivories and Court Women in the Umayyad Court at Córdoba," in Pearls on a String: Art in the Age of Great Islamic Empires, ed. Amy Landau (Seattle: University of Washington Press, 2015), 28-51.

41 John Williams, "León: The Iconography of a Capital," in Cultures of Power, ed. T. Bisson (Philadelphia: University of Pennsylvania Press, 1995), 231-258, at 237. For the Cross and the Beatitudes Casket, see Chpt. 2 by Therese Martin in this volume. For León as a cosmopolitan Iberian capital in a globally-oriented world, see Chpt. 7 by Pamela A. Patton, "Demons and Diversity in León" in the present volume.

42 For a detailed analysis of the iconography of other portable altars as well as their function in defining ritual space, see Palazzo, L'espace rituel, esp. Chpt. 6.

43 In personal communications, both Jessica Boon and Ittai Weinryb suggested to me that the stretched-out animal could be a hyena, a deceptive, filthy, and bisexual animal that has been connected to the Jews for its traitorous nature. See Debra Hassig, Medieval Bestiaries: Text, Image, Ideology (Cambridge: Cambridge University Press, 1995), 144-145. As Jessica Boon pointed out, perhaps Psalm 21:17 inspired the iconography: quoniam 
certainly not unusual on portable altars; however, these composite creatures that appear to be made up of different animals are unique. The roaring ones that threaten the Lamb have the tails of lions, the snouts of dragons or wolves, and the pelts of other animals altogether, while below, one of the beasts has the spotted fur of a leopard but not its head or tail. The creature under attack has a ridge of hair running from head to tail, like that of a hyena, but it lacks the large ears typical of this animal, and its tail is unlike any real creature's. By depicting hybrid monsters that were even more terrible than recognizable wild animals, the artist emphasized the beastly nature of would-be attackers of Christ. When the altar is held vertically, the Agnus Dei tramples the beasts below, symbolizing Christ's sacrificial triumph over death, which is also commemorated and celebrated on the altar. The altar was evidently conceived as an object in motion not only in the inscription around the edges, but also in surface ornamentation that must be viewed horizontally as well as vertically. This design must have been intentional because inscription and images are engraved in the same sheet of silver that holds the stone in place.

Parallels have been sought for this imagery at San Isidoro beginning in 1925 with Manuel Gómez-Moreno, who connected the style of the Agnus Dei, the symbols of the four evangelists, and the fantastic animals to the Bible made in 1162 at San Isidoro by itinerant manuscript illuminators. ${ }^{44}$ His idea was seconded by Ángela Franco Mata, but it has recently been convincingly contested by Ana Hernández, who sees no clear stylistic connections between the tetramorph in the 1162 Bible and the evangelist symbols depicted in the corners of the altar. ${ }^{45}$ Eduardo Álvarez Aller found a different Leonese referent in the symbols of the evangelists on the Fernando and Sancha Cross, the Saints John the Baptist and

circumdederunt me canes multi concilium malignantium obsedit me foderunt manus meas et pedes meos (For many dogs have encompassed me: the council of the malignant hath besieged me. They have made holes in my hands and feet). The dogs mentioned in the Psalm have been identified with the Jews' tormenting of Christ. See Irven M. Resnick, Marks of Distinction: Christian Perception of Jews in the High Middle Ages (Washington, D.C.: Catholic University of America Press, 2012), 148-150. The animal imagery on Sancha's altar, however, is too ambiguous to be interpreted as explicitly anti-Jewish.

44 Archivo de la Real Colegiata de San Isidoro de León, Códice III. See Gómez-Moreno, Catálogo monumental, 1:206.

45 Franco Mata, "El tesoro de San Isidoro," 67; Ana Hernández, "Nuevas aproximaciones en torno a la Maiestas de la Biblia de 1162 de San Isidoro de León en el Museo Arqueológico Nacional (Madrid)," Archivo Español de Arte 9o/358 (2017): 183-19o. Michael Budde insisted on a León production for the altar because he considered the Infanta its patron and San Isidoro its recipient, see Budde, Altare portatile, 2:cat. 98, 229-232, at 231. For a brief description of the Bible of 1162, see John Williams, "Bible," in The Art of Medieval Spain. AD 500-1200 (New York: Metropolitan Museum of Art, 1993), cat. 15 o. 
Pelayo Casket, and the Traditio Legis ivory at the Louvre. ${ }^{46}$ While it is true that the arms of the ivory cross are decorated with the symbols of the four evangelists, there is neither stylistic nor pictorial affinity with those represented on the altar (Figure 6.6). And while the tetramorph and Agnus Dei from the lid of the reliquary casket and on the Traditio Legis ivory reveal an interest in the execution of furs, feathers, and hair, here too the styles differ too much to argue any direct connection between the ivories and the metalwork (Figures 6.7a, b). ${ }^{47}$ In fact, I can see no stylistic evidence for locating the manufacture of Sancha's altar in León.

Rather, given Anselm's episcopal seat in Bethlehem, it seems reasonable to suggest that artists working in the Levant may have made the altar. Although there is scant evidence of goldsmiths working at Bethlehem in the first half of the twelfth century, in Jerusalem, by contrast, a street was named for the goldsmiths whose workshops clustered there. ${ }^{48}$ Quite a number of True Cross reliquaries were made in Jerusalem; they generally take the form of a doublearmed cross of wood decorated with gilded silver and precious stones. Many were brought back to European lands by elite pilgrims, crusaders, and settlers, while others were presented by the ecclesiastical foundations of the crusader states to affiliated monastic institutions in the west. ${ }^{49}$ Some Iberian donations of these staurothekai are known, testifying to ties across the Mediterranean. ${ }^{50}$ And yet, it is not easy to connect the style and technique in which the figures on Sancha's altar have been executed to metalwork produced in Jerusalem. The latter are dominated by medallions in high relief, flower patterns, and pearl motifs, whereas the altar's decoration is incised in gilt silver with niello, resulting in clear contours and crisp details.

In sum, an analysis of the altar's style and iconography cannot by itself solve the riddle of the place of manufacture, nor does it offer any support for the presumed Leonese origin. Rather, it is the unusual aspects of the inscription

46 Álvarez Aller, "El ara de la infanta," 9.

47 For an image of the Traditio Legis ivory, see John Williams, "Christ in Majesty with Saints Peter and Paul," in The Art of Medieval Spain, cat. 112.

48 Jaroslav Folda, The Art of the Crusaders in the Holy Land, 1098-1187 (Cambridge: Cambridge University Press, 1995), 99-100 and 29o. When art from the crusader states is addressed, the focus is mostly on sculpture, architecture, and (manuscript) painting; there seems to be less evidence for locally made minor arts, despite the street of goldsmiths in Jerusalem. See T.S.R. Boase, "Ecclesiastical Art in the Crusader States in Palestine and Syria," in A History of the Crusades, vol. IV: The Arts and Architecture of the Crusader States, ed. Harry W. Hazard (Madison: The University of Wisconsin Press, 1977), 69-139, at 139.

49 Folda, The Art of the Crusaders, 290-294 on reliquaries of the True Cross; and Nikolas Jaspert, "The True Cross of Jerusalem in the Latin West: Mediterranean Connections and Institutional Agency," in Visual Constructs of Jerusalem, 207-221. Jaspert, "The True Cross of Jerusalem," 221. 


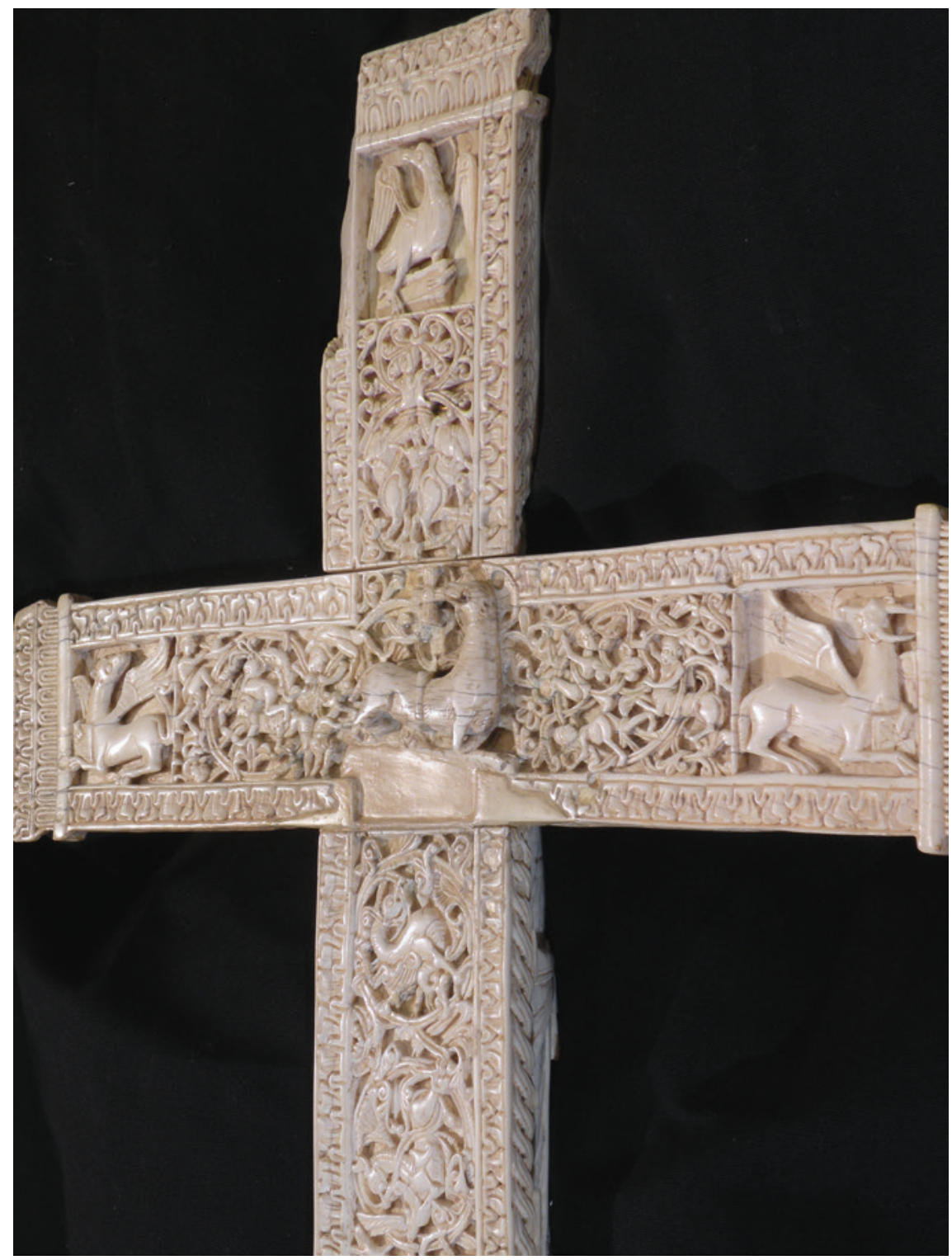

FIgURE 6.6 Cross of Fernando and Sancha (reverse), ca. 1063, 54.2 × $34 \mathrm{~cm}$. (Madrid, Museo Arqueológico Nacional, Inv. No. 52340). See also Figs. 2.4a, 2.4b. PHOTO: THERESE MARTIN 

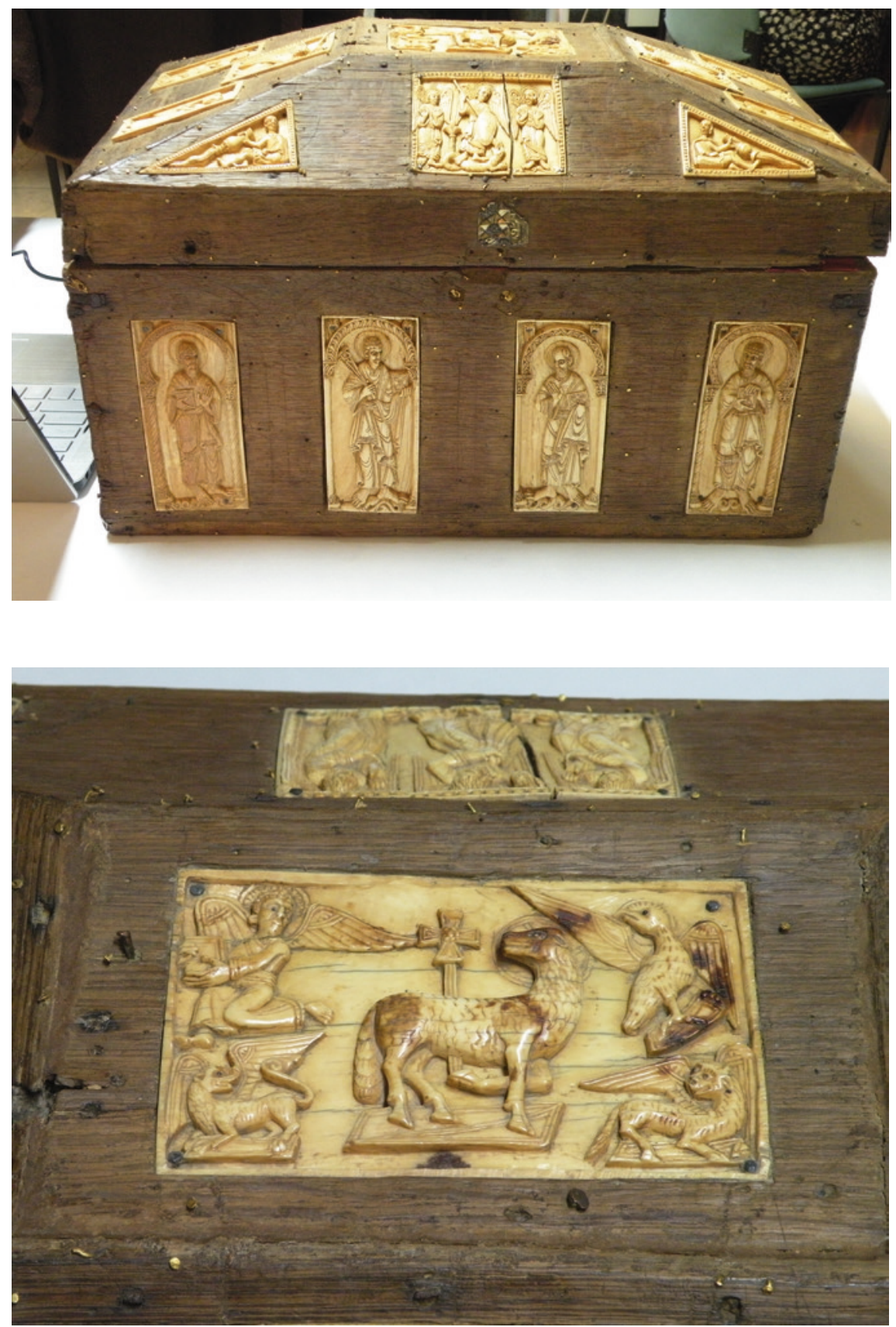

FIGURES 6.7A, B A., Casket of Saints John the Baptist and Pelayo; B., detail of lid, late eleventh century, $31 \times 48 \times 26 \mathrm{~cm}$. (Museo de la Real Colegiata de San Isidoro de León, Inv. No. IIC-3-o89-0o2-0o23). See also Figs. 1.8, 4.12a, 4.12b, 5.6, 5.9. PHOTOS: THERESE MARTIN 
that suggest that the work was done under the orders of someone far from the politics of early twelfth-century León. Distance would both account for its unusual dating and also offer an explanation for the individual presence of Count Raimundo. According to a general patrilineal logic, Sancha's father would have been the obvious family member to select for inclusion in the inscription. Based on the oddities in the inscription together with its consecration by Anselm of Bethlehem, we can therefore speculate that the altar's maker was from the Levant. If a definitive setting for the origins of the altar must remain an open question for now, it is hoped that bringing this piece to wider scholarly attention will contribute to its future resolution.

\section{$4 \quad$ Material Matters: Stones Narrating the Life of Christ}

The altar's contents, as listed in the inscription, contribute to the exotic nature of this object from a distant land, a spirit also imbued by its multicolored stone slab. Thinking of artworks in terms of their material presence, beyond their function and patronage, reflects a current in scholarship that is attuned to a nuanced understanding of the essential and tangible qualities of objects. These are understood not as resulting from solely artistic or functional processes, but as holding an active potential; that is, materials are recognized as having the ability to affect the beholder's actions and imagination. ${ }^{51}$

Most surviving portable altars have precious slabs made of porphyry, jasper, alabaster, white marble, or rock crystal. From descriptions in chronicles and in the inventories of church treasuries, the attention paid to altar slabs is evident, due to their association with the body of Christ. ${ }^{52}$ Comparing the evidence from visual and written sources with the stone in Sancha's altar shows how truly extraordinary its multicolored slab is. This stone has been identified either as red marble or limestone, with the dominant color being read symbolically as though it were porphyry, and thus an affirmation of royal ties. ${ }^{53}$ Although the reddish color certainly is present, a variety of greens, yellows, and greys are easily visible as well. In fact, the slab is a natural composite of multicolored

$5^{1} \quad$ Karen Overbey, "Materiality and Place in a Medieval Scottish Pendant Reliquary," Res:Anthropology and Aesthetics 65/66 (2014/2015):242-258, esp. 243-244 with references.

$5^{2}$ Braun, Der christliche Altar, 428 and 430-433.

53 Laura Rodríguez Peinado, "Pýrpura. Materialidad y simbolismo en la Edad Media," Anales de Historia del Arte 24 (2014): 471-495, at 48o. The stone was previously identified as red marble by Llamazares, El tesoro, 175, and by Bango García, “Ara de San Isidoro (León)," 352. A reddish limestone was put forward by Gómez-Moreno, Catálogo monumental, 1:206, and by Franco Mata, "El tesoro de San Isidoro," 67. 
stones known as breccia di Aleppo, which was quarried under the Romans on the Greek Island of Chios. ${ }^{54}$ Breccia is uncommon on the Iberian Peninsula, underscoring the probable origin of this object from elsewhere, and it may offer an example of the re-use of valued materials..$^{55}$ Like other marbles, this colorful and unusual stone was appreciated for its ability to shine brightly after being polished, yet its selection for this altar, with its remarkable collection of relics from places rather than persons, invites a reading of the stone's composite nature in connection to the different holy locations named in the inscription. The conglomerate, exotic appearance of the slab visually reiterates the story told on the altar's edges of many stones and multiple sites, thus serving as an "active agent of meaning" while triggering the beholder's senses. ${ }^{56}$ The sensorial nature of holy stones is evidenced by a sixth-century pilgrim's account that tells of a deformed stone placed in position by Jesus when he visited Mount Zion. This stone was treated by pilgrims as a relic that could be held, touched, and even listened to because it produced a sound. ${ }^{57}$

Taking into consideration that some altar slabs were appreciated not just for their costliness or rarity, but because of their unique history, I would argue that the multicolored slab in Sancha's altar was deliberately chosen because it resembles a natural collection of stones encapsulating all the rocks, mountains, and other concrete locations mentioned in the inscription. In this way, the exotic altar stone functioned as a guide to the viewer's imagination by making tangible the inscribed holy sites that were geographically far away yet materially close at hand. ${ }^{58}$

54 I owe the identification of this stone to Ignacio Montero Ruiz and Sergio Vidal. The Russian pilgrim Daniel the Abbot mentions Chios as part of his route from Kiev to Jerusalem. Chios is where the holy martyr St. Isidoro (d. 252) is buried and where "mastic and good wine and every kind of vegetable" are produced. See Wilkinson, Jerusalem Pilgrimage, 122. Ana Gutiérrez García-Moreno pointed out to me that breccia di Aleppo was also uncommon in the Western Mediterranean in ancient times and therefore it rarely surfaced in the Middle Ages in places where previous Roman objects were reused.

56 See Alicia Walker, The Emperor and the World: Exotic Elements and the Imagining of Middle Byzantine Imperial Power, Ninth to Thirteenth Centuries C.E. (Cambridge: Cambridge University Press, 2012), xx. Despite being a postmedieval concept, scholars have addressed exoticism as an aesthetic mode from a medieval perspective. See, for example, Shayne Aaron Legassie's idea of "the prestige of long-distance knowledge" in The Medieval Invention of Travel (Chicago and London: University of Chicago Press, 2017), 22.

57 This account is in the Itinerarium by (Pseudo-)Antonius Placentinus. See Thomas O'Loughlin, “'Remembering Sion:' Early Medieval Latin Recollections of the Basilica on Mount Sion and the Interplay of Relics, Tradition, and Images," in Visual Constructs of Jerusalem, 1-11, esp. 4-5.

$5^{8}$ For the role of material culture in bridging space and time, see Gertsman and Mittman, "Rocks of Jerusalem," 163 . 
The altar's remarkable inscription, curious iconography, exotic materiality, and essential mobility work together to evoke both earthly and spiritual Jerusalem, which would have aided Sancha's devotions during her lifetime. But the altar's biography does not stop there. In the early modern period, a legend arose - perhaps sparked by this very object — that Sancha had traveled to the Holy Land. After all, the altar's inscription might lead one to assume that a pilgrimage had taken place during which the material remains of holy sites and persons were collected, and it would have been there and then that Bishop Anselm consecrated the multicolored stone that was enshrined in silver in 1144. Yet nothing in the medieval written record, whether Sancha's charters or the twelfth- or thirteenth-century chronicles that make reference to the infanta, indicates her absence from León-Castilla, much less a trip to the Holy Land. ${ }^{59}$ Nor is any mention made of a pilgrimage in Lucas of Tuy's Liber miraculorum beatissimi Isidori, which is the most detailed, almost hagiographic, narrative source about Sancha. It seems extremely unlikely that Lucas would have ignored such a significant journey in his fulsome praise of the infanta. ${ }^{60}$

In fact, it is not until the sixteenth century that a textual source first bears witness to this tale. Ambrosio de Morales's trip of 1572-1573 through northern Spain at the order of King Felipe II is the earliest surviving source mentioning Sancha's travels to the Holy Land, although he does so not in his discussion of San Isidoro but rather in his narrative of the monastery of San Pedro de la Espina. Sancha had granted to Bernard of Clairvaux various inheritances belonging to Espina so that he could build a monastery, of which Morales knew because at Espina he read "the foundational charter" (la Escritura de la fundacion), for which he gives no date. ${ }^{61}$ The focus in Morales's story is on Bernard

59 García Calles, Doña Sancha, 6o.

6o Liber miraculorum beatissimi Isidori, esp. cap. xxxv, 6o-63. For an analysis of Sancha's portrayal in the Liber miraculorum, see Henriet, "Hagiographie et politique à León," 70-71.

61 Ambrosio de Morales, Viage de Ambrosio de Morales por orden del Rey D. Phelipe II a los Reynos de León, y Galicia y Principado de Asturias, ed. Enrique Flórez (Madrid, 1765 [ca. 1572]), 186. The earliest transcription of the Espina charter was made in the seventeenth century by Ángel Manrique, who gives 1143 as the monastery's foundation, and he too mentions Sancha's travels, although in less detail than Morales; Manrique clearly had some doubts, stating that it was a "traditione quam scripto magis accipimus." See Ángel Manrique, Annales cistercienses, 4 vols. (Lyon: 1642), 2:86. See also José Luis Rodríguez de Diego, El tumbo del monasterio cisterciense de la Espina (Valladolid: Universidad de Valladolid, Secretario de Publicaciones, 1982), 48 (on Manrique), 53 (the cartulary accepts Sancha's pilgrimage), and 186 (the text of the privilege). Rodríguez de Diego 
of Clairvaux and on the French royal abbey of St. Denis because they help to understand both the foundation of Espina and its relic collection. Although Morales's reference is rather vague and the tale of Sancha's pilgrimage must be legendary, her connection to the abbot of Clairvaux did, in fact, exist: the infanta donated to Bernard certain possessions of the Cistercian monasteries of San Pedro de Espina and Santa María de Aborridos. She also placed the monastery of Toldanus under his protection, concerning which Bernard wrote two letters to Sancha, an indication of direct personal communication between the two. ${ }^{62}$

This Iberian-French connection, already suggested by the use of indiction in the inscription, invites a positioning of the altar within Sancha's wider dynastic network. Here we might consider other "pathways of portability" for the object's exotic character: perhaps the infanta's interest in the Christian East was part of her father's legacy. ${ }^{63}$ Although Count Raimundo never went overseas, his cousin Odo of Burgundy, with whom Raimundo originally had arrived in Iberia, took part in the Holy Land Crusade of 1101. This was just two years after the liberation of Jerusalem and the finding of a part of the True Cross, events that not only led to a more fervent veneration of the Cross, but also made the Holy Land itself a relic to be visited. ${ }^{64}$ The crusades also directly impacted the Leonese-Castilian royal family, as Elvira, a half-sister of Sancha's mother Urraca, had accompanied her husband Raymond of Toulouse on the First Crusade in 1096, and she gave birth in the Holy Land to Alfonso Jordan, as his sobriquet indicates. ${ }^{65}$

did not include a transcript of the text that narrates Sancha's voyage on fols. $47^{\mathrm{r}}-5$ ov. For a brief overview of the foundation of Espina, see Artemio Manuel Martínez Tejera, "Castromonte," in Enciclopedia del Románico en Castilla y León: Valladolid, dir. Miguel Ángel García Guinea and José María Pérez González (Aguilar de Campoo: Fundación Santa María la Real, Centro de Estudios del Románico, 2002), 143-156, at 143.

62 Martín López, "Colección documental de la Infanta," nos. 38 and 53; García Calles, Doña Sancha, 88-9o. For the letters, see https://epistolae.ctl.columbia.edu/woman/164.html. For the larger context of Cistercian monasticism in twelfth-century Iberia and women's patronage in particular, see James D'Emilio, "Widows and Communities: Cistercian Nunneries and Their Architecture in the Kingdom of León (1150-1300)," Cîteaux. Commentarii Cistercienses 66/3-4 (2015): 223-302.

63 Eva Hoffman, "Pathways of Portability: Islamic and Christian Interchange from the Tenth to the Twelfth Century," Art History 24/1 (2001): 17-5o.

64 Jaspert, "The True Cross," 207-221; William J. Purkis, Crusading Spirituality in the Holy Land and Iberia, c. 1095-1187 (Woodbridge: The Boydell Press, 2008), 64-65.

65 For Iberian crusaders journeying to the Holy Land and their dynastic ties, see Margarita C. Torres Sevilla-Quiñones de León, "Cruzados y peregrinos leoneses y castellanos en Tierra Santa ss. XI-XII," Medievalismo 9 (1999): 63-82; and Ana Rodríguez, "Remembering the Crusades while Living the Reconquest: Iberia, Twelfth to Fourteenth Centuries," in Remembering the Crusades and Crusading, ed. Megan Cassidy-Welch (Abingdon: Routledge, 2017), 202-215. For Galicia, see Carlos Andrés González-Paz, 
Sancha's lifetime saw her father's brother, Guy of Vienne, elected pope at the Abbey of Cluny in 1119, where he took the name Calixtus II (d. 1124). ${ }^{66}$ At the First Lateran Council in 1123 the pontiff proclaimed that those who had promised to take the cross should fulfill their vow before Easter 1124 by going either to the Holy Land or to Spain. ${ }^{67}$ Even though there is no reference to Calixtus in Sancha's charters, ${ }^{68}$ she must have been familiar with his proclamation, especially since the pope also offered an indulgence to those fighting in Hispania for the Christian cause. One of these miles Christi was King Alfonso I of Aragón (d. 1134), Queen Urraca's second husband, who considered himself to be as much a crusader as those going to the Levant. ${ }^{69}$ All this makes it likely that Sancha would have been aware of the attractions of the Latin East through members of her elite network, such as Bernard of Clairvaux, including her kinship groups. Instead of viewing the relics in her altar as the result of a pilgrimage, it is more fruitful to consider them as reflecting Sancha's interests in a holy landscape that allowed her to remain in her temporal holdings in Iberia while simultaneously making the spiritual iter to Jerusalem.

In the end, Sancha's portable altar, with its seemingly straightforward record of an elite woman's patronage, raises more questions than it answers. In this article I have applied a range of historical and art historical methodologies to the analysis of a twelfth-century object, demonstrating its connections to both León and the Levant and suggesting its impact on later history. This container, made of silver, gold, and a multicolored stone covering holy fragments of multiple materials, offers evidence of the importance of materiality to Sancha and other medieval beholders. A moveable item that encapsulated transportable saintly remains, this artifact invites an assessment of its place within Sancha's web of connections. While the genesis of her altar cannot yet be definitively

"Guncina González volens ire Iherusalem," in Women and Pilgrimage in Medieval Galicia, ed. Carlos Andrés González-Paz (Farnham: Ashgate, 2015), 51-64. For a Catalonian example, see Nikolas Jaspert, "Un vestigio desconocido de Tierra Santa: La vera creu d'Anglesola," Anuario de Estudios Medievales 29 (1999): 447-475.

66 Purkis, Crusading Spirituality, 131.

67 Patrick J. O'Banion, "What Has Iberia to Do with Jerusalem? Crusade and the Spanish Route to the Holy Land in the Twelfth Century," Journal of Medieval History 34/4 (2008): $383-395$, at 387 .

68 Cavero, "Sancha Raimúndez," 275.

69 Purkis, Crusading Spirituality, 133-137. 
resolved, my reading shows that the altar's exotic content, together with exoticism as its aesthetic mode, can be understood in relation to the significance of the Holy Land for the elite circles of which Sancha was a part. Yet, for as much as we now know about this object, the altar as a multilayered artifact still fits only too well with Oleg Grabar's assessment that the "most remarkable works of art are those that remain meaningful and intriguing, because somewhat mysterious, to all those who deal with them." ${ }^{70}$ I can only hope that the venerable scholar would agree.

\section{Acknowledgments}

Republication of this study in the present volume was supported by the Index of Medieval Art (Princeton University) and The Medieval Iberian Treasury in Context: Collections, Connections, and Representations on the Peninsula and Beyond (National Research Challenge Grant, Spanish Ministry of Science, Innovation, and Universities, AEI/FEDER, RTI2018-o98615-B-Ioo, 2019-2O22, PI Therese Martin).

70 Oleg Grabar, "About a Bronze Bird," in Reading Medieval Images: The Art Historian and the Object, ed. Elizabeth Sears and Thelma K. Thomas (Ann Arbor, MI: The University of Michigan Press, 2002), 117-125, at 124. 